Мадис РУБЕЛЬ*, Антанас БРАЗАУСКАС**, Петрас МУСТЕИККИС*, Нвар ПУУРА*

\title{
РАСПРЕДЕЛЕНИЕ ВЕНЛОКСКИХ БРАХИОПОД В РАЗРЕЗЕ СУУРИКУ, ЭСТОНИЯ
}

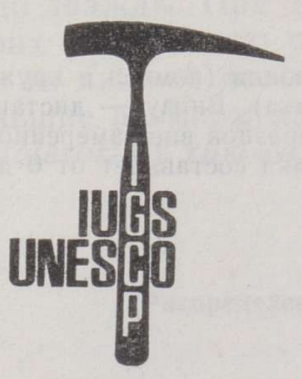

\section{ГЛОБАЛЬНЫЕ} БИОСОБЫТ ИЯ

Расположенный на северо-западной окраине о-ва Сааремаа клиф Суурику (максимальная высота около 11 м) изучался летом 1986 г. в целях дополнения палеонтологических коллекций. В настоящей статье изложены данные о распределении брахиопод, полученные в ходе этих работ.

Коренные породы клифа Суурику - венлокские известняки ниназеской пачки яаниского горизонта $\left(\mathrm{J}_{1} \mathrm{~N}\right)$ - под действием штормового волнения подвергаются разрушению (см. Аалоэ, 1970). Более мергелистая мустъялаская пачка того же горизонта $\left(\mathrm{J}_{1} M\right)$ обнажается только вдоль самой подошвы клифа на протяжении около 200 м, а также на дне моря, где образует недалеко от береговой линии подводный уступ.

Клиф Суурику вытянут метров на 400 в сторону ЮВВ и слегка дугообразно на 125 м в направлении Ю3. Образованный таким образом выступ береговой линии, маркированный остатками затонувшего судна, был выбран в качестве опорной точки для данного' обнажения.

По всему клифу обнажаются одни и те же слои, пересеченные несколькими наклонными трещинами (Klaamann, 1961). Из-за чередования мергелистых пород и более чистых известняков на стенке клифа образовалось несколько карнизов, позволяющих прослеживать соответствующие им слои и в труднодоступных местах клифа. Наиболее выдвинутый карниз образован плотными известняками в низах ниназеской пачки, под которыми остаются мергели с прослоями известняков мустъялаской пачки. Эта хорошо выраженная граница между названными пачками выбрана в качестве опорного уровня для данного обнажения.

Используя опорные точку и уровень, все наблюдения и места взятия образцов мы фиксировали двумя векторами - направленной дистанцией интересующей нас точки от опорных точки и уровня в метрах. Например, образец 15 отобран в 157 м ЮВВ и 0,15 м $\uparrow$ (см. рисунок).

Ниназеская пачка в точке, расположенной в 175 м ЮВВ, состоит из следующих слоев снизу вверх, м (см. рисунок):

* Eesti Teaduste Akadeemia Geoloogia Instituut Эстонии). 200105 Tallinn, Estonia pst. 7, Estonia.

** Geologijos ir mineralogijos katedra Vilniaus universitetas (кафедра геологии и минералогии Вильнюсского университета). 232000 Vilnius, Ciurlionio 21/27, Lietuva. 


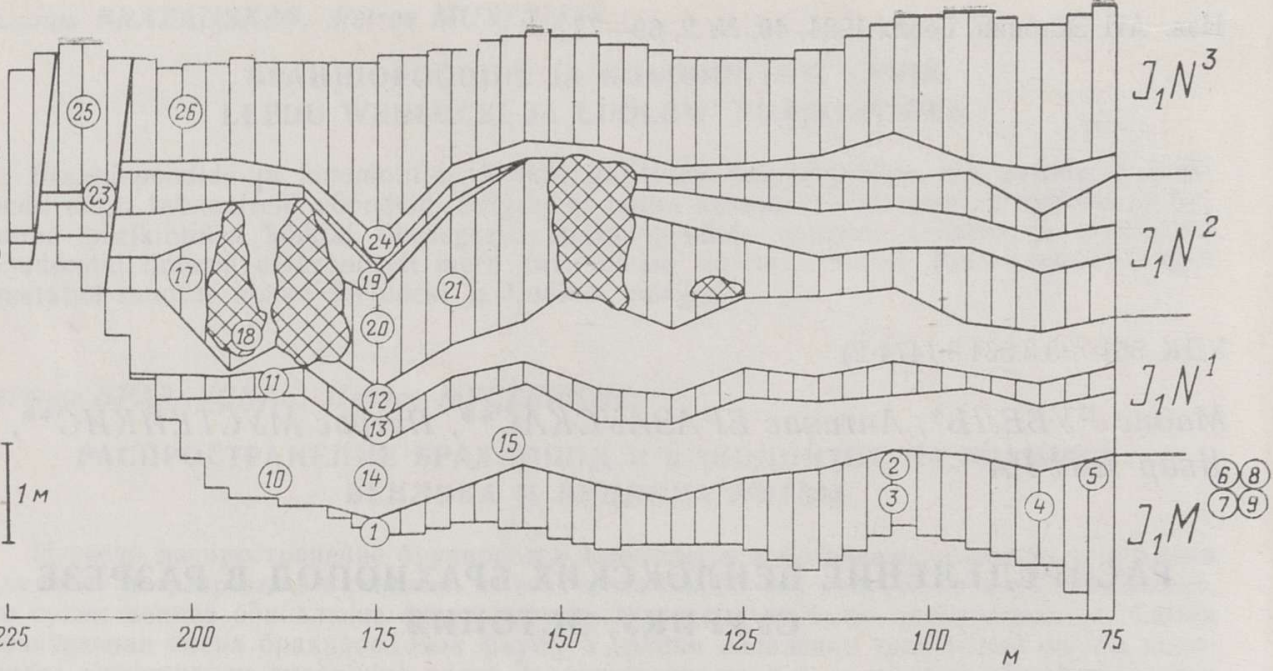

Расположение карнизов, биогермов (сетчатая штриховка) и образцов (номера в кружках) в замеренной части клифа Суурику (вертикальная штриховка). Внизу - дистан ция в метрах от опорной точки. Стратиграфическое положение образцов вне замеренной стенки клифа дано приблизительно, их дистанция от опорной точки составляет от 0 до 70 м для образцов $6-9$ и 235 м для образцов 16 и 22.

0,77 - известняк серый, плотный, криноидный, образец 14 ;

0,43 - переслаивание детритового известняка с онколитами и мергеля с мшанками, образец 13;

0,45 - известняк серый, плотный, детритовый с онколитами и тонкими прослоями мергеля, образец 12 ;

0,90 - известняк комковатый, с прослоями мергеля, комки сложены детритовым известняком с криноидеями и брахиоподами, образец 20;

0,35 - известняк детритовый, плотный с криноидеями, онколитами и брахиоподами, образец 19 ;

1,20 - переслаивание детритового брахиоподового известняка и мергеля, образец 24 взят из одного маркирующего (показанного отдельно карниза) прослоя известняка в низах данного слоя.

На многих береговых обрывах о-ва Сааремаа в яаниском горизонте распространены небольшие мшанковые биогермы, доминирующими организмами в которых служат мшанки из родов Ceramopora и Lioclema (Аалоэ, 1970). Такие биогермы встречаются в средней части разреза Суурику (слои мощностью $0,45,0,90$ и 0,35 м в приведенном выше разрезе) и подразделяют здесь отложения ниназеской пачки на три части далее обозначаемые верхними индексами (см. рисунок) .

По имеющимся представлениям, отложения ниназеской пачки считаются мелководными (Аалоэ, 1970). На клифе Суурику они представлены регрессивной последовательностью, подчеркнутой к тому же подстилающими нормально-морскими мергелями мустъялаской пачки. Согласно устному сообщению Р. Эйнасто, условия осадконакопления отложений по выделенным выше подразделениям интерпретируются следующим образом: $\mathrm{J}_{1} \mathrm{M}$ - открытый шельф, $\mathrm{J}_{1} \mathrm{~N}^{1}-$ предрифовое (предбиогермное) мелководье, $\mathrm{J}_{1} \mathrm{~N}^{2}-$ зона образования рифов (биогермов), $\mathrm{J}_{1} \mathrm{~N}^{3}$ - зарифовая (забиогермная) лагуна. 
В ходе полевых работ 1986 г. было отобрано всего 26 образцов, пред̈ставляющих собой в большинстве случаев мергелистую породу весом 1-4 кг. Образцы сначала обрабатывались 10\%-ным раствором перекиси водорода, а затем водой для отмывки глинистых частиц. Ископаемые организмы отбирались из отмытого остатка под бинокуляром. Пять из 26 образцов $(10,15,22,25$ и 26-й) представляли собой лишь находки отдельных экземпляров или образцы без описанной выше обработки.

Остановимся подробнее на распределении брахиопод по названным выше подразделениям. Следует сразу отметить, что находки родов Linoporella, Ravozetina, Atrypina и Salopina являются первыми из рассматриваемого обнажения. В то же время здесь не было обнаружено ни одного экземпляра трех видов - Platystrophia jaaniensis, Cyrtia trapezoidalis, Estonirhynchia estonica, известных по ранним коллекциям из разреза клифа Суурику (Рубель, 1963, 1970; Рубель, Рымусокс, 1970). Тем не менее дополнение коллекции брахиопод 32 видами из 35 всего установленных позволяет оценить представительность коллекции 1986 г. весьма высоко.

Представители родов Whitfieldella и Dolerorthis перечислены в таблице дважды. При этом неидентифицированные до вида экземпляры обоих родов часто распространены в образцах из мустъялаской пачки или из нижней половины ниназеской пачки. Они имеют значительно меньшие размеры раковины, чем экземпляры видов Whitfieldella nitida и Dolerorthis rustica, встреченных в основном в верхах ниназеской пач-

\section{Распределение венлокских брахиопод по выделенным слоям}

Eoplectodonta duvalii

Visbyella visbyensis

Skenidioides lewisii

Resserella sabrinae

Gypidula sp. ?

Pholidostrophia laevigata

Linoporella sp.

Dicoelosia sp.?

Dictyonella sp.

Ravozetina sp.

Nucleospira pisum

Whitfieldella sp.

Rhynchotreta cuneata

Craniops sp.

Isorthis sp.

Dolerorthis sp.

Howellella sp.

Dalejina $\mathrm{sp}$.

Leptostrophia sp.

Eospirifer radiatus

Meristina podolica

Coolinia sp.

Salopina tubulata

Atrypa reticularis

Leptaena sp.

Hemitoechia undvaensis

Megastrophia semiglobosa

Eocoelia angelini

Striispirifer striatellus

Atrypina barrandii

Plectatrypa sp.

Dolerorthis rustica

Microsphaeridiorhynchus nucula Whitfieldella nitida

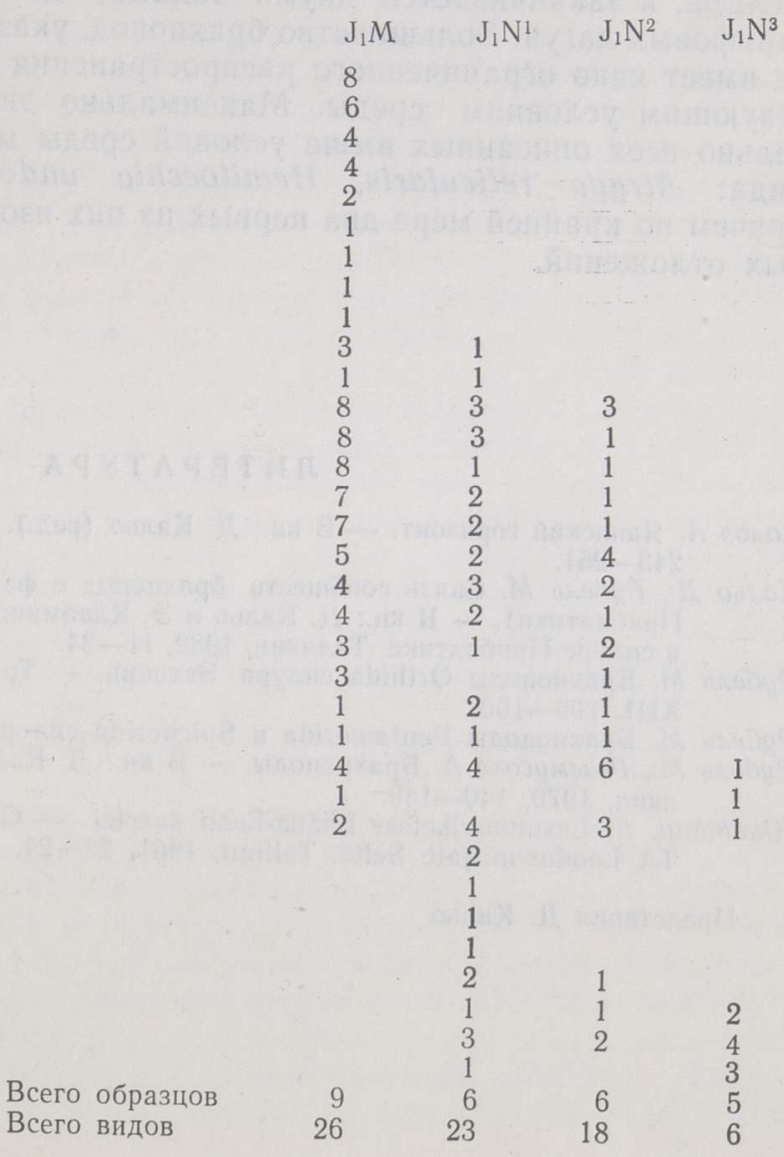


ки. Вероятно, первые (маленькие) формы тоже могут быть отнесены к названным видам. В данном случае они перечислены все же отдельно, как особые экоморфы, подчеркивающие разницу между условиями осадконакопления рассматриваемых слоев.

Характеризуя общие тенденции распределения брахиопод в ниназеской пачке данного обнажения, можно отметить постепенное уменьшение разнообразия брахиопод в сторону стратиграфически более молодых слоев (см. таблицу). Такая тенденция связывается с влиянием общего обмеления венлокского моря в данном месте, причем из-за отсутствия специфических брахиопод в изученных биогермах она носит плавный характер. Более того, в этих биогермах вообще не было найдено брахиопод, несмотря на целенаправленные поиски. Слой $\mathrm{J}_{1} \mathrm{~N}^{3}$, литологически больше остальных отклоняющийся от нормально-морских отложений, характеризуется малым числом видов, но зато здесь наблюдается массовое скопление раковин брахиопод Microsphaeridiorhynchus nucula и Whitfieldella nitida. В частности, последний вид является породообразующим по нескольким прослоям в слое $\mathrm{J}_{1} \mathrm{~N}^{3}$. В терминах брахиоподовых сообществ, установленных и по силуру о-ва Сааремаа (Кальо, Рубель, 1982), брахиоподы из мустъялаской пачки данного обнажения рассматриваются еще в пределах сообщества Dicoelosia-Skenidioides. В то же время брахиоподы из ниназеской пачки относятся уже к сообществу Whitfieldella, хотя состав его претерпевает здесь значительное обеднение, особенно в самых верхних слоях.

Итак, можно говорить о наличии явного фациального контроля в распределении брахиопод в разрезе Суурику. Поэтому список брахиопод в приведенной таблице начинается с видов, населявших дно открытого шельфа, и заканчивается двумя видами, доминирующими в условиях зарифовых лагун. Большинство брахиопод, указанных в середине списка, не имеет явно ограниченного распространения по отношению к соответствующим условиям среды. Максимально эврифациальными относительно всех описанных выше условий среды могут служить только три вида: Atrypa reticularis, Hemitoechia undvaensis и Leptaena sp., причем по крайней мере два первых из них изобилуют все же вне лагунных отложений.

\section{ЛИ Т Е РА Т У Р А}

Аалоэ A. Яаниский горизонт. - В кн.: Д. Кальо (ред.). Силур Эстонии. Таллинн, 1970 $243-251$.

Кальо Д., Рубель М. Связь сообществ брахиопод с фациальной зональностью (силур Прибалтики). - В кн.: Д. Кальо и Э. Клааманн (ред.). Сообщества и биозоны в силуре Прибалтики. Таллинн, $1982,11-34$.

Рубель М. Брахиоподы Orthida силура Эстонии. - Тр. Ин-та геол. АН ЭССР, 1963, XIII, $109-160$

Рубель М. Брахиоподы Pentamerida и Spiriferida силура Эстонии. Таллинн, 1970.

Рубель М., Рыьммусокс А. Брахиоподы. - В кн.: Д. Қальо (ред.). Силур Эстонии. Таллинн, $1970,140-149$.

Klaamann, E. Lasumusriketest Lääne-Eesti saartel. - Geoloogilised märkmed, 2. ENSV TA Loodusuurijate Selts. Tallinn, 1961, 22-24.

Представил Д. Кальо

Поступила в редакцию 20/XI 1990 
Madis RUBEL, Antanas BRAZAUSKAS, Petras MUSTEIKIS, Ivar PUURA

\section{WENLOCKI BRAHHIOPOODIDE LEVIK SUURIKU LÄBILOIKES EESTIS}

Suuriku pangal paljanduvad lubjakivid on moodustunud järjest madalduvas Wenlocki meres. 32 brahhiopoodiliigi leviku uurimine näitas, et koos mere madaldumisega muutus liigivaesemaks ka brahhiopoodide kooslus.

Madis RUBEL, Antanas BRAZAUSKAS, Petras MUSTEIKIS and Ivar PUURA

DISTRIBUTION OF WENLOCK BRACHIOPODS IN THE SUURIKU SECTION, ESTONIA

Wenlock limestones of the Suuriku cliff in the north-west of Island Saaremaa belong to the Mustjala $\left(J_{1} M\right)$ and Ninase members $\left(J_{1} N\right)$ of the Jaani Stage, representing offshore and near-reef sediments respectively. The Ninase Member can be subdivided into three beds $\left(J_{1} N^{1}\right.$ is the lowermost one), the origin of each of them is in turn connected with fore-, inter- and back-reef environments, respectively.

The distribution of 32 brachiopod species from 26 samples shows a gradual decrease in their diversity in ascending order (shallowing-up sequence). No brachiopods have been found in the bioherms themselves. 